\title{
ע Asiantuntijoiden näkemyksiä palliatiivisen hoidon ja saattohoidon kehittämis- ja tutkimustarpeista
}

\begin{abstract}
Palliatiivinen hoito tarkoittaa parantumatonta, kuolemaan johtavaa tai henkeä uhkaavaa sairautta sairastavan potilaan ja hänen läheistensä aktiivista, kokonaisvaltaista hoitoa. Maailman terveysjärjestön mukaan palliatiivisen hoidon tarve kasvaa lähitulevaisuudessa eniten Euroopassa suhteutettuna väestöön. Suomessa on tutkittu varsin vähän asiantuntijoiden näkemyksiä palliatiivisen hoidon kehittämistarpeista. Tämän tutkimuksen tarkoituksena oli kuvata palliatiivisen hoidon ja saattohoidon asiantuntijoista $(n=222)$ koostuneiden työryhmien $(n=36)$ näkemyksiä alan tärkeimmistä kehittämis- ja tutkimuskohteista lähitulevaisuudessa. Tutkimuksen aineisto kerättiin keväällä 2018, ja se koostui työryhmien työpajoissa tuottamista kahden avokysymyksen vastauksista. Aineisto analysoitiin teemoittelemalla sisältö. Tulosten mukaan palliatiivisen hoidon ja saattohoidon tärkeimmät kehittämiskohteet liittyivät toiminnan puitteiden, hoitokäytäntöjen sekä osaamisen kehittämiseen. Tärkeimmät tutkimuskohteet liittyivät toimintaympäristöön, potilaaseen, hoitoon, läheisiin, ammattihenkilöihin, vapaaehtoistyöhön sekä monitieteiseen tutkimukseen. Tutkimus tuotti tärkeää tietoa siitä, mitkä ovat tärkeimmät elämän loppuvaiheen hoidon kehittämiskohteet, jotta tasa-arvoinen ja tasalaatuinen hoito pystytään toteuttamaan asuinpaikasta riippumatta. Työryhmien mukaan tutkimusta olisi suunnattava laajasti hoidon kaikkïn osa-alueisiin.
\end{abstract}

ASIASANAT: palliatiivinen hoito, saattohoito, kehittäminen, tutkimustyö SIRPA SALIN, HANNA-LEENA MELENDER, JUHO T. LEHTO, MINNA HÖKKÄ

\section{YDINASIAT}

- Suomi sijoittuu kansainvälisessä palliatiivisen hoidon vertailussa toiseksi edistyneimpien maiden joukkoon, mutta eurooppalaisessa vertailussa viimeisten joukkoon.

- Palvelujärjestelmän rakenteiden ja prosessien kehittäminen on tärkeää palveluiden tasaarvoisen saatavuuden varmistamiseksi myös haja-asutusalueilla.

- Hoidon laadun varmistamiseksi tarvitaan monitieteellisiä hoitosuosituksia sekä monitieteellistä tutkimusta ja lisäksi hoidon vaikuttavuuden seurantaa.

- Tuloksia voidaan hyödyntää tutkimuskohteiden valinnassa ja hoidon kehittämisessä.

\section{TUTKIMUKSEN LÄHTÖKOHDAT}

Maailman terveysjärjestön (WHO) arvion mukaan palliatiivisen hoidon tarve suhteutettuna väestöön kasvaa lähitulevaisuudessa eniten Euroopassa. Keskeisinä syinä ovat väestön ikääntyminen ja kroonisten sairauksien lisääntyminen. (1.)

Palliatiivinen hoito tarkoittaa parantumatonta, kuolemaan johtavaa tai henkeä uhkaavaa sairautta sairastavan potilaan ja hänen läheistensä aktiivista, kokonaisvaltaista hoitoa. Hoidon tavoitteina ovat potilaan fyysisen, psyykkisen, sosiaalisen ja eksistentiaalisen kärsimyksen ehkäiseminen ja lievittäminen sekä potilaan ja hänen läheistensä elämänlaadun parantaminen (2). Palliatiivinen hoito ei ole ajallisesti rajattua, ja se voi kestää jopa vuosia. Saattohoito on osa palliatiivista hoitoa, joka ajoittuu ihmisen viimeisille elinviikoille tai -päiville. $(3,4$.) 
Palliatiivinen hoito tulisi integroida osaksi sosiaali- ja terveyspalvelujärjestelmää. $(1,5,6$.) Palliatiivinen hoito on ihmisoikeus, jonka tulisi olla kaikkien saatavilla (7). Tämän varmistamiseksi on perustettu kansainvälinen työryhmä, joka laati palliatiivisen hoidon kehittämisen etenemissuunnitelman. Suunnitelma palvelee laajana viitekehyksenä eri organisaatioita, ja siinä huomioidaan kaikki tarvittavat osatekijät ja vaiheet palliatiivisen hoidon integroimiseksi osaksi palvelujärjestelmää (5). Tarvitaan edelleen huomattavaa panostusta maailmanlaajuisesti, jotta palliatiivinen hoito on kaikkien saatavilla (8).

Lynchin tutkimusryhmän (2013) (8) tekemän selvityksen mukaan maailman valtioista $(n=234)$ yli puolella $(58 \%)$ oli vähintään yksi palliatiiviseksi hoidoksi luokiteltava palvelu. Kuusiportaisessa arvioinnissa vain 20 maata ylsi palliatiivisen hoidon järjestämisessä kaikkein edistyneimpien maiden ryhmään, Ruotsi ja Norja mukaan lukien. Suomi kuului toiseksi edistyneimpään ryhmään, jossa palliatiivisen hoidon integrointi yleiseen palvelujärjestelmään on alkuvaiheessa. Tähän ryhmään kuuluvissa maissa esimerkiksi pyritään laajalti palliatiivisen hoidon käyttöönottoon, terveydenhuollon ammattilaiset ovat aiheesta laajalti tietoisia ja alan toimijoille on perustettu tai ollaan perustamassa omaa järjestöä. Suomen Palliatiivisen Hoidon Yhdistys (SPHY) (9) perustettiin vuonna 1995 ja Palliatiivisen Lääketieteen Yhdistys (SPLY) (10) vuonna 2003.

Eurooppalaisessa vertailussa Suomi on sijoittunut viimeisiin maihin palliatiivisen hoidon kehittämisessä $(11,12)$. Resursseja kuvaavat indikaattorit vertailussa olivat palliatiivisen hoidon sairaansijat ja saattohoitokodit, sairaalan asiantuntijatiimit ja kotihoidon tiimit. Toiminnan vireyttä kuvaavat indikaattorit olivat kansallisen yhdistyksen elinvoimaisuus, palveluhakemisto, lääkäreiden akkreditointi, osallistuminen alan konferensseihin ja tuotetut julkaisut (11).

Suomessa on viime vuosina kehitetty palliatiivista hoitoa valtakunnallisesti $(13,14)$. Hoidon järjestämisessä siirrytään parhaillaan kolmiportaiseen malliin, jossa hoitopaikat jaetaan tasoihin niiden tarjoaman hoidon vaativuuden mukaan. Perustason muodostavat kaikki sosiaali- ja terveydenhuollon yksiköt, joissa hoidetaan kuolevia potilaita. Perustason A-tason yksiköt ovat niitä yksiköitä, joissa saattohoitoa kehitetään yhtenä perustehtävänä muun toiminnan ohessa. Erityis- tason (B) palveluverkon muodostavat sairaanhoitopiirien palliatiiviseen hoitoon ja saattohoitoon erikoistuneet yksiköt. Vaativan erityistason (C) muodostavat yliopistosairaaloiden palliatiiviset keskukset (14).

Tehtyjen selvitysten perusteella alueelliset erot erityisesti erityistason palveluiden saatavuudessa vaihtelevat, joten potilaat ovat eriarvoisessa asemassa riippuen asuinpaikasta. Harvoissa sairaaloissa on alan konsultaatiotoimintaa, eikä sitä ole saatavissa päivystysaikaan. Myös erityistason kotisaattohoidon kattavuus on puutteellinen. Selvityksen mukaan saattohoitoa toteutetaan pääasiassa perustason yksiköissä, joissa henkilöstön osaaminen vaihtelee (14). Laadukkaan hoidon turvaamiseksi Suomessa on julkaistu palliatiivisen hoidon ja saattohoidon Käypä hoito -suositukset (Lääkäriseura Duodecim) (4) ja hoitotyön suosituksia (Hoitotyön Tutkimussäätiö) valmistellaan parhaillaan potilaan suun hoidosta, läheisen tukemisesta sekä lääkkeettömistä kivunhoitomenetelmistä. (15). Lisäksi ammatillisen koulutuksen toteutumisesta on tehty selvityksiä parhaillaan käynnissä olevassa EduPal (Palliatiivisen hoitotyön ja lääketieteen koulutuksen monialainen ja työelämälähtöinen kehittäminen) -hankkeessa (16).

Palliatiivisen hoidon palvelujen kehittäminen on keskeistä, sillä oikea-aikainen ja laadukas palliatiivinen hoito mahdollistaa potilaan paremman hoidon ja läheisten tukemisen sekä vähentää terveydenhuollon kustannuksia. (17-19.) Hyvin toimiva palliatiivinen hoito vähentää lisäksi päivystyskäyntejä ja potilaan ohjautumista kalliiseen erikoissairaanhoitoon (3). Palliatiivisen hoidon optimaalisen järjestämisen kannalta pelkkä keskittyminen erityistason hoitoon ei riitä vastaamaan potilaiden ja perheiden tarpeisiin elämän lopussa. $(20,19$.)

Palliatiivista hoitoa on tutkittu paljon niin kansainvälisesti kuin kansallisesti. Viime aikoina tutkimusta on tehty esimerkiksi ammattihenkilöstön osaamisen (21), päätöksenteon (22) ja ohjausosaamisen (23) näkökulmista. Sen sijaan korkeatasoista palliatiivisen hoidon arviointitutkimusta tarvitaan lisää (24). Hasson ja työryhmä (25) tunnistivat järjestelmällisessä katsauksessaan palliatiivisen hoidon tärkeimpiä tutkimuskohteita ja totesivat, että kymmenestä valitusta alkuperäistutkimuksesta yhdessä tutkittavina oli ollut vain potilaita, kahdessa potilaita ja perheitä, kuudessa 
tutkijoita, kahdessa tutkijoita ja kliinisessä työssä toimivia, yhdessä kansalaisia ja kahdessa vapaaehtoistyöntekijöitä. Katsauksessa tunnistetut tärkeimmät tutkimusalueet olivat palvelumallit, hoidon jatkuvuus, koulutus, epätasa-arvo, kommunikaatio, hyvä ja itsenäinen elämä, sekä perheen tai hoitavan henkilön tarpeet ja perheiden tärkeys. Tämä EduPal-hankkeessa tehty tutkimus pyrkii vastaamaan siihen haasteeseen, että kliinisessä työssä ja muissa potilaan ja perheiden auttamistehtävissä toimivilta palliatiivisen hoidon ja saattohoidon ammattilaisilta on kerätty suhteellisen harvoin tietoa siitä, mitkä heidän näkemyksensä mukaan ovat tärkeitä alan kehittämis- ja tutkimuskohteita.

\section{TARKOITUS JA TUTKIMUSKYSYMYKSET}

Tämän tutkimuksen tarkoituksena on kuvata palliatiivisen hoidon ja saattohoidon ammattilaisten näkemyksiä alan tärkeimmistä kehittämis- ja tutkimuskohteista lähitulevaisuudessa. Tutkimuskysymykset ovat seuraavat:

1. Mitkä ovat ammattilaisten näkemysten mukaan palliatiivisen hoidon ja saattohoidon tärkeimmät kehittämiskohteet lähitulevaisuudessa?

2. Mitkä ovat ammattilaisten näkemysten mukaan palliatiivisen hoidon ja saattohoidon tärkeimmät tutkimuskohteet lähitulevaisuudessa?

\section{AINEISTO JA MENETELMÄT}

\section{TUTKIMUSAINEISTON KERUU}

Aineisto kerättiin ammattilaisille järjestetyissä työpajoissa. Työpaikkojen esihenkilöitä pyydettiin ehdottamaan henkilöstöstään ammattilaiset, jotka pystyisivät kuvailemaan palliatiivisen hoidon ammattilaisilta vaadittavaa osaamista. Esihenkilöiden suosittelemille henkilöille lähetettiin kutsukirje, joka sisälsi tiedot tutkimuksen tarkoituksesta, perusteluista ja vastuuhenkilöistä.

Tarkoituksenmukainen otos alalla työskentelevistä ammattilaisista kutsuttiin osallistumaan ammattikorkeakoulujen järjestämiin työpajoihin eri puolilla Suomea. Otokseen $(\mathrm{N}=222)$ kuului edustajia useista terveydenhuollon organisaatioista ja potilasjärjestöistä seuraavasti: perustason lääkärit $(n=12)$; sairaanhoitajat $(n=63)$ ja lähihoitajat $(\mathrm{n}=25)$; palliatiivisen lääketieteen erityispätevyyslääkärit (n=16); sairaanhoitajat $(n=69)$ ja lähihoitajat $(n=10)$; kolmannen sektorin asiantuntijat $(\mathrm{n}=7)$; vanhustyön ammattilaiset $(\mathrm{n}=1)$; sosiaalityöntekijät $(\mathrm{n}=3)$; fysioterapeutit $(\mathrm{n}=3)$; hoitotyön johtajat $(\mathrm{n}=9)$ ja hengellisen työn ammattilaiset $(\mathrm{n}=4)$.

Hankkeeseen osallistuvien 15 ammattikorkeakoulun (amk) opettajat järjestivät työpajat kevään 2018 aikana omilla toiminta-alueillaan. $\mathrm{Ne}$ toteutettiin joko ammattikorkeakouluissa tai työpajojen jäsenten työpaikoilla. Joissakin tapauksissa samaan työpajaan kutsuttiin sekä perus- että erikoistason edustajat omiksi työryhmikseen. Kaikkiaan aineistoa kerättiin 36 työryhmältä 21 työpajassa. Työpajojen moderaattorit olivat ammattikorkeakoulujen opettajia.

Työpaja-aineistot kerättiin kyselylomakkeella. Moderaattorit aloittivat työpajat esittelemällä projektin ja ohjeet työpajatyöskentelylle. Kukin työryhmä sai kyselylomakkeen, joka oli kehitetty tätä tiedonkeruuta varten. Se koostui kymmenestä avoimesta kysymyksestä, joissa kysyttiin ammattilaisten näkemyksiä palliatiivisessa hoidossa vaadittavasta osaamisesta sekä muista palliatiivisen hoidon ja saattohoidon kehittämiseen liittyvistä asioista, joista kaksi koski alan kehittämisja tutkimustarpeita (tutkimuskysymykset 1 ja 2). Näiden kysymysten tulokset raportoidaan tässä tutkimusartikkelissa. Kyselylomake oli esitestattu yhdessä työryhmässä. Sen perusteella ei ollut tarvetta tehdä muutoksia kyselylomakkeeseen, jolloin esitestanneen työryhmän suostumuksella aineisto voitiin sisällyttää varsinaiseen tutkimusaineistoon.

Kyselylomakkeen kysymysten mukaisesti jokainen työryhmä keskusteli näkemyksistään ja valitsi keskuudestaan kirjurin, joka dokumentoi yhteiset vastaukset. Joissain tapauksissa dokumentaatio tehtiin tietokoneella, kuitenkin useimmiten paperilla. Moderaattorit eivät osallistuneet keskusteluihin, mutta he olivat käytettävissä kysymysten selventämiseksi. Lisäksi he seurasivat keskusteluja ja tekivät kenttämuistiinpanoja. Työpajojen kesto vaihteli kahdesta neljään tuntiin.

\section{AINEISTON ANALYYSI}

Aineisto analysoitiin teemoittelemalla sisältö (26). Lähestymistapa oli induktiivinen eli aineistolähtöinen, mikä tarkoittaa etenemistä yksittäisistä havainnoista yleisempiin väitteisiin. Tällöin ana- 
lyysiyksiköt eivät ole ennalta määrättyjä, eikä tutkija määrää sitä, mikä on tärkeää, vaan teoriaa rakennetaan aineisto lähtökohtana (27). Analyysin ensimmäisessä vaiheessa aineistoon tutustuttiin lukemalla se läpi useaan kertaan kokonaiskuvan saamiseksi. Analyysiyksiköksi valittiin sana, lause tai ajatuskokonaisuus. Nämä analyysiyksiköt eli alkuperäiset ilmaisut kuvasivat palliatiivisen hoidon ja saattohoidon tärkeimpiä kehittämiskohteita (239 lausumaa) ja tutkimuskohteita (204 lausumaa). Analyysin toisessa vaiheessa alkuperäiset ilmaisut pelkistettiin, niitä vertailtiin ja ne ryhmiteltiin samankaltaisiin sisältökokonaisuuksiin eli teemoihin. Teemoista muodostetuille alateemoille annettiin sisältöä kuvaavat nimet. Alateemoja ryhmittelemällä ja yhdistelemällä saatiin palliatiivista hoitoa ja saattohoitoa kuvaavat tärkeimmät kehittämiskohteet (Kuvio 1) sekä niiden tärkeimmät tutkimuskohteet (Kuvio 2). Taulukossa 1 esitetään esimerkki aineiston abstrahoinnista.

Taulukko: Esimerkki yläteemaan ”toimintaympäristö" liittyvästä aineiston abstrahoinnista.

\begin{tabular}{|c|c|c|}
\hline Pelkistetty ilmaus & Alateema & Yläteema \\
\hline $\begin{array}{l}\text { - hoitojen tasavertainen saatavuus } \\
\text { eri puolilla Suomea } \\
\text { - potilaan oikeuksien toteutuminen muuttuvilla } \\
\text { sote-hallintoalueilla }\end{array}$ & $\begin{array}{l}\text { Potilaan oikeudet } \\
\text { hoitoon eri puolilla } \\
\text { Suomea }\end{array}$ & \multirow{2}{*}{$\begin{array}{l}\text { Toimintaympäristöön } \\
\text { liittyvät } \\
\text { tutkimuskohteet }\end{array}$} \\
\hline $\begin{array}{l}\text { - hoidon saatavuus eri hoitoympäristöissä } \\
\text { - potilaiden kokemukset eri hoitoympäristöistä } \\
\text { - retrospektiivinen selvitys potilaiden kuolinpaikoista }\end{array}$ & $\begin{array}{l}\text { Eri hoitoympäristöt } \\
\text { hoidon toteuttajina }\end{array}$ & \\
\hline
\end{tabular}

\section{TUTKIMUKSEN EETTISYYS}

Tutkimuksessa noudatettiin hyvää tieteellistä käytäntöä (28) ja ihmiseen kohdistuvan tutkimuksen eettisiä periaatteita (29). Eettisen toimikunnan lausunnon hakemisen tarvetta tiedusteltiin Pohjois-Pohjanmaan sairaanhoitopiirin eettiseltä toimikunnalta, jonka mukaan tutkimusluvan hakeminen ei edellyttänyt eettisen toimikunnan lausuntoa. Osallistuminen tutkimukseen oli vapaaehtoista ja osallistujat allekirjoittivat suostumuslomakkeen. Tietoisen suostumuksen varmistamiseksi tutkimukseen kutsuttavia informoitiin tutkimuksesta kirjallisesti ja suullisesti. Tutkimusaineistojen tunnistetiedoiksi merkittiin työryhmien numerot, ei yksittäisten osallistujien tietoja, ja aineisto säilytettiin salassa.

\section{TULOKSET}

\section{ALAN AMMATTILAISTEN NÄKEMYKSET PALLIATIIVISEN HOIDON JA SAATTOHOIDON TÄRKEIMMISTÄ KEHITTÄMISKOHTEISTA LÄHITULEVAISUUDESSA}

Ammattilaisia pyydettiin kuvaamaan palliatiivisen hoidon ja saattohoidon tärkeimmät kehittämiskohteet lähitulevaisuudessa. Aineiston analyysissä kehittämiskohteiksi jäsentyivät toiminnan puitteiden, hoitokäytäntöjen sekä osaamisen kehittäminen (Kuvio 1). 


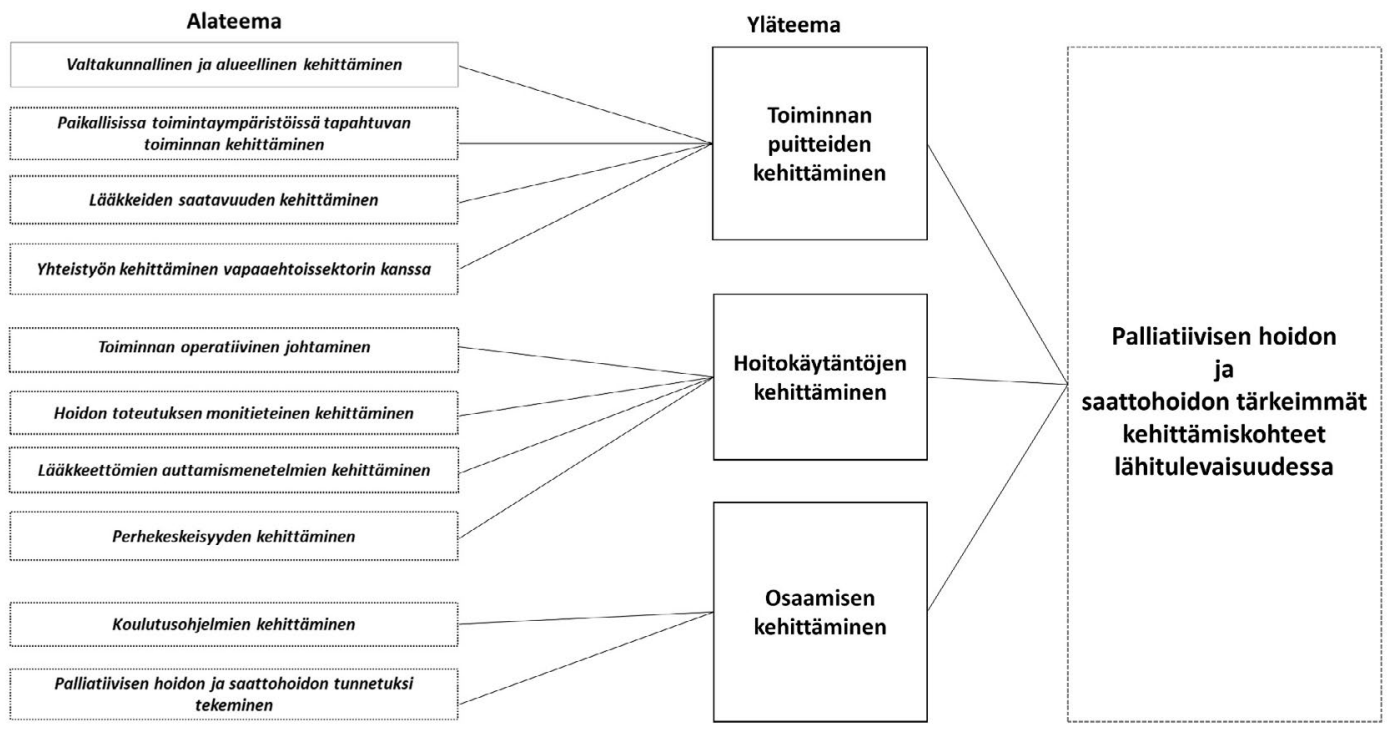

Kuvio 1. Alan ammattilaisten (n=222) näkemykset palliatiivisen hoidon ja saattohoidon tärkeimmistä kehittämiskohteista lähitulevaisuudessa.

\section{TOIMINNAN PUITTEIDEN KEHITTÄMINEN}

Valtakunnallisessa ja alueellisessa kehittämisessä kuvattiin ammattilaisten näkemykset palliatiivisen hoidon ja saattohoidon yhdenvertaisen saatavuuden välttämättömyydestä kaikkialla Suomessa. Erityisesti etähoidon kehittäminen haja-asutusalueilla ja rajaseutuyhteistyö naapurimaiden kanssa olivat tärkeitä kehittämiskohteita varsinkin Pohjois-Suomessa, jotta valtakunnallisesti yhtenäinen hoito voitaisiin taata. Tärkeänä pidettiin myös valtakunnallisesti yhtenäistä potilastietojärjestelmää, johon ammattilaisilla olisi myös käyttöoikeudet.

Paikallisissa toimintaympäristöissä tapahtuva toiminnan kehittäminen sisälsi mahdollisuuden järjestää kotisaattohoitoa sekä yleisesti kotisairaalatoiminnan kehittämisen, jossa moniammatillinen yhteistyö toteutuisi joustavasti potilaan parhaaksi. Erityistason yksiköitä kuvattiin tarvittavan lisää, samoin tarkoituksenmukaisia välineitä ja tiloja, jotka olisivat myös esteettisesti kauniita.

”oireilevat syöpäpotilaat kuormittavat päivystystä, heille täytyisi olla joku toinen reitti hoitoon"
Lääkkeiden saatavuuden kehittäminen vaatisi ammattilaisten mukaan nykyistä joustavampia malleja, sillä lääkkeiden saatavuus apteekeista on toisinaan hankalaa. Apteekkien roolia palliatiivisen lääkehoidon saatavuuden parantamisessa pitäisi tarkastella myös uudelleen.

"Kelan määräysvalta lääkkeistä, saattohoidon lääkkeistä tarvitaan joustavampia malleja esim. morfiinin hinnoittelu”

Lääkehoitoon liittyvää lainsäädäntöä tulee ammattilaisten näkemysten mukaan myös kehittää, sillä nykymuotoisena se saattaa jopa hankaloittaa toimintaa. Lääkkeiden luovuttaminen osastolta potilaalle hänen kotiutuessaan ei ole kaikissa tilanteissa mahdollista, mikä ajoittain vaikeuttaa potilaan kotihoitoa. Sosiaalihuoltolain piirissä olevien, hoivapalveluja tuottavien yksiköiden edellytykset toteuttaa saattohoitoa katsottiin olevan rajalliset ilman lääkehuollon lainsäädännön muutosta.

"terveydenhuollon ulkopuolella toimivien yksiköiden (esim. hoivakodit) lääkehuollon lainsäädännöllinen muutos on ehdoton, että saattohoitoa voidaan siellä toteuttaa." 
Yhteistyön kehittäminen vapaaehtoissektorin kanssa sisälsi työryhmien näkemysten mukaan kehittämistarpeet vapaaehtoisten mukaan ottamisessa, heidän apunsa hyödyntämisessä ja heidän kouluttamisessaan toimimaan ammattilaisten rinnalla aiempaa systemaattisemmin. Vapaaehtoisia tarvitaan lisää, etenkin koulutettuja vapaaehtoisia. Kolmannen sektorin toimintaan pitäisi saada lisää vapaaehtoisia ja heidän toimintaansa pitää myös rahoittaa, jotta tämä onnistuu.

"kolmannen sektorin hyödyntäminen yksinäisten potilaiden kohdalla”

\section{HOITOKÄYTÄNTÖJEN KEHITTÄMINEN}

Toiminnan operatiivisen johtamisen kehittämisessä olisi työryhmien mukaan tärkeintä ympärivuorokautisen konsultaatiomahdollisuuden ja moniammatillisen yhteistyön edistäminen. Haja-asutusalueilla näitä tavoitteita voisi tukea liikkuvien yksiköiden perustaminen ja mahdollisuus ensihoidon kiireettömiin arviointikäynteihin.

”Ammattilaisten ryhmä, joka panostaa pelkästään palliatiiviseen hoitotyöhön ja saattohoitoon”.

Työryhmän mukaan omahoitaja- ja omalääkärimallien kehittäminen olisi tarpeellista henkilöstön pysyvyyden ja työhyvinvoinnin lisäämiseksi. Malli edellyttää asianmukaista henkilöstömitoitusta. Hoitohenkilöstön työhyvinvointiin tulee panostaa sekä palkitsemisjärjestelmää monipuolistaa.

"hoitotyöntekijöille työaikajoustoa tilanteen mukaan. Jos potilaana on saattohoitoa vaativa henkilö, voi hoitaja pystyessään tehdä pidemmän päivän ja kun hoidon tarvetta ei enää ole, voi työaika normalisoida (saako ylityöt sitten aikana tai rahana). Varallaolorinki? Erityisesti haja-asutusalueilla.”

Hoidon toteutuksen monitieteisessä kehittämisessä kohteita ovat hoidon monitieteisyys ja ihmisläheisyys sekä sen näyttöön perustuvuus. Ammattilaisten näkemysten mukaan ihmislähtöisessä hoidossa potilaan toiveet ja tarpeet konseptoitaisiin palliatiiviseksi hoidoksi, joka sisältää erityisesti ammattilaisten ja läheisten läsnäolon sekä oire- ja kivunhoidon. Lasten ja vammaisten saattohoidon kehittäminen ovat vastaajien mukaan tär- keitä osa-alueita. Myös muiden kuin syöpäpotilaiden hoitoa pitää kehittää. Koko maahan tulee luoda yhtenäiset hoitolinjaukset, joita kaikki sitoutuvat noudattamaan.

"yhtenäinen linjaus hoitorajausten kirjaamiseen (ER [elvytyskielto]/DNR [elvyttämättäjättämispäätös]/AND [sallitaan luonnollinen kuolema] /SLK [sallitaan luonnollinen kuolema]: SLK: sallitaan luonnollinen kuolema: tämä haluttaisiin käyttöön, koska on ymmärrettävä ja suomen kieltä.”

Teknologian hyödyntäminen on työryhmien mukaan yksi kehitettävä osa-alue. Etälääkärivastaanotot ja muut etähoitomahdollisuudet hyödyttävät erityisesti haja-asutusalueiden palliatiivisen hoidon ja saattohoidon kehittämistä. Teknologian kehittyminen ja yleistyminen mahdollistavat potilaan tilan seurannan esimerkiksi älykellojen avulla.

"videoneuvotteluyhteydet, seniorilääkärikierrot. Turhien potilassiirtojen välttäminen. Hoidon saatavuus ja tasavertaisuus.”

Lääkkeettömien auttamismenetelmien kehittäminen kohdistaa huomion vaihtoehtoisiin kivunhoito- ja oirehoitomenetelmien tunnistamiseen ja kokeiluun. Läsnäolo, kosketus sekä henkisten ja hengellisten tarpeiden tunnistaminen ovat ihmislähtöisen hoidon tärkeitä osa-alueita. Keskiössä ovat lääkkeettömien hoitomenetelmien aiempaa monipuolisempi tarjonta, kehittäminen, kokeilu ja arviointi.

Perhekeskeisyyden kehittäminen konkretisoituu etenkin lapsiperheiden huomioimisessa osana hoitoa. Lasten huomioiminen läheisinä ja psykososiaalisen tuen tarjoaminen perheille ovat perhehoitotyön sisältöjä, samoin yleensäkin yhteistyön lisääminen läheisten kanssa. Ammattilaiset ehdottivat, että läheisille tarjottaisiin mahdollisuus palkalliseen saattohoitovapaaseen, jotta tämä onnistuisi. Omaisten selviytyminen ja jälkituen järjestäminen heille potilaan kuoleman jälkeen ovat osa perhekeskeisyyden kehittämistä.

"omaisten mukana olo ja huomiointi, koska heillä on suuri merkitys potilaan hoidossa... kansalaisaloite mahdollisuudesta omaishoidon vapaaseen" 


\section{OSAAMISEN KEHITTÄMINEN}

Koulutusohjelmien kehittäminen tarkoittaa kunkin koulutusalan sisällä saman sisältöisten opetussuunnitelmien luomista koko valtakuntaan, jolloin koulutukset olisivat vastaajien näkemysten mukaan tasalaatuisia kaikkialla Suomessa. Osaamista kuvaavien mittareiden luominen sekä osaamistasojen kuvaukset ja niiden arviointikriteerit toisivat yhtenevyyttä. Ammatillisten perustutkintojen, kuten ensihoitajakoulutuksen ja lähihoitajakoulutuksen, sisältöjen kehittäminen on työryhmien mukaan kiireellisintä. Täydennyskoulutuksessa pitäisi varmistaa psykiatrisen hoitohenkilöstön ja kotihoidon henkilöstön osaaminen. Muistija syöpäsairaiden kohtaamiseen ehdotettiin täydennyskoulutusta. Osaamisen kehittäminen on mahdollista virtuaaliteknologiaa hyödyntämällä. Se auttaisi myös verkosto-osaamisen vahvistamista.

"lähihoitajille erityiskoulutusta saattohoitoon ja kuolevan potilaan hoitoon sisältäen geriatrisen potilaan hoidon. Ja riittävän laaja lääkehoidon tietämys. Lähihoitajille tulee olla oma kriteeristö palliatiivisen ja saattohoidon osaamisen suhteen. Erityisesti palvelutaloissa. Liittyy mm. lupaan antaa lääkkeitä (kipupumppu)”
Palliatiivisen hoidon ja saattohoidon tunnetuksi tekeminen tarkoittaa, että ensinnäkin suurelle yleisölle ja terveydenhuollon henkilöstölle tulisi tehdä tutuksi näiden käsitteiden sisällöt. Toiseksi elämän loppuvaiheen hoitojen esillä pitäminen edistäisi ammattilaisten mukaan suhtautumista kuolemaan osana elämänkaarta.

Hoitotahdosta tiedottaminen ja sen markkinointi kaikille kansalaisille edistäisi hoitotahdon tekemistä, mikä helpottaisi elämän loppuvaiheen hoitoa potilaan omien toiveiden mukaisesti.

"miten markkinoimme hoitotahtoa, että se jokaisella olisi."

\section{ALAN AMMATTILAISTEN NÄKEMYKSET PALLIATIIVISEN HOIDON JA SAATTOHOIDON TÄRKEIMMISTÄ TUTKIMUSKOHTEISTA LÄHITULEVAISUUDESSA}

Ammattilaisia pyydettiin kuvaamaan palliatiivisen hoidon ja saattohoidon tärkeimmät tutkimuskohteet lähitulevaisuudessa. Tärkeimpiä tutkimuskohteita kuvasivat seuraavat seitsemän yläteemaa: 1) toimintaympäristöön, 2) potilaaseen, 3) hoitoon, 4) läheisiin, 5) ammattihenkilöstöön, 6) vapaaehtoistyöhön ja 7) monitieteiseen tutkimukseen liittyvät tutkimuskohteet (Kuvio 2).

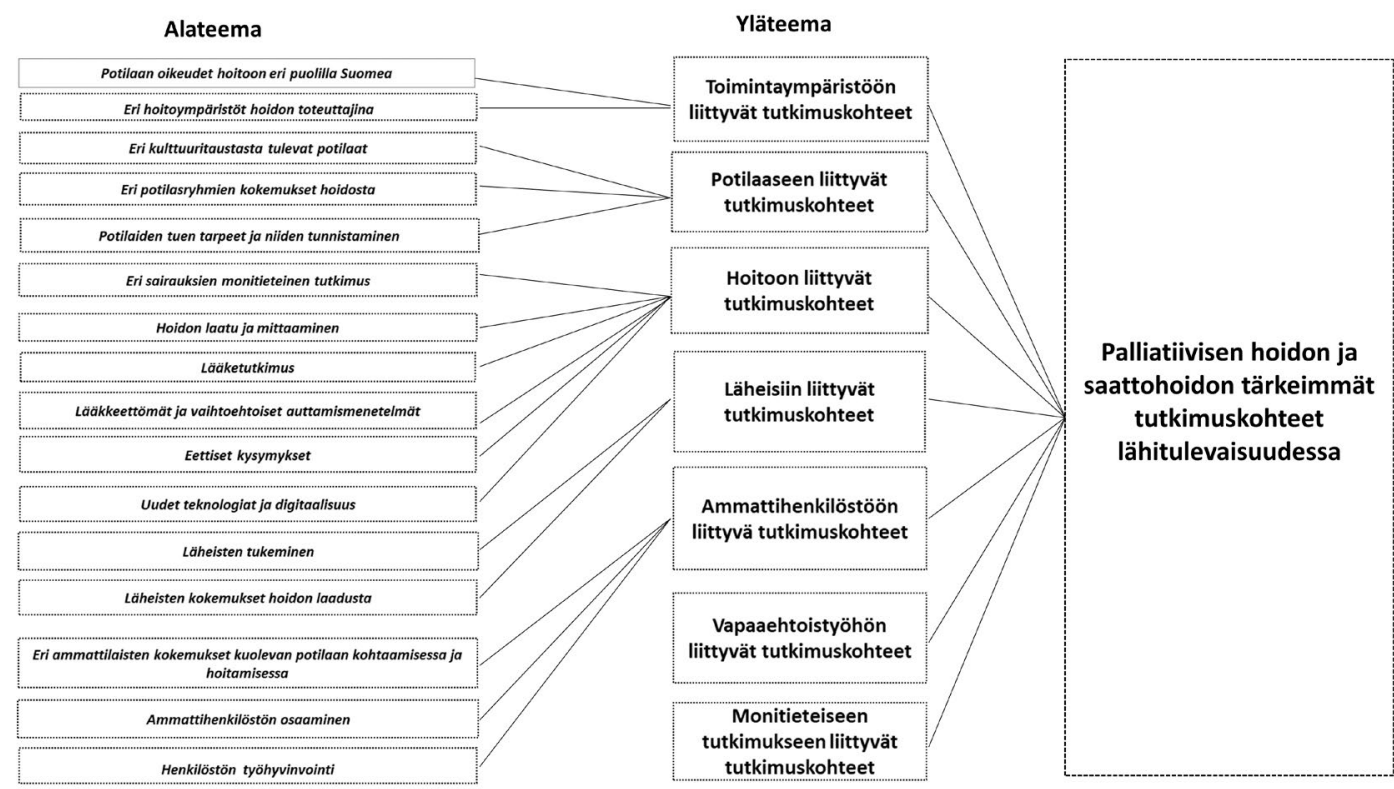

Kuvio 2. Alan ammattilaisten ( $n=222$ ) näkemykset palliatiivisen hoidon ja saattohoidon tärkeimmistä tutkimuskohteista lähitulevaisuudessa 


\section{TOIMINTAYMPÄRISTÖÖN LIITTYVÄT TUTKIMUSKOHTEET}

Vastaajien mukaan potilaiden oikeudet palliatiiviseen hoitoon ja saattohoitoon eri puolilla Suomea on tärkeä tutkimuskohde, sillä etenkin uudistuva sosiaali- ja terveydenhuolto tuo mukanaan rakenteellisia muutoksia sosiaali- ja terveydenhuollon hallintoalueisiin. Tutkimusta tarvitaan nimenomaan siitä, miten palliatiivinen hoito ja saattohoito toteutuvat eri asuinpaikoilla Suomessa ja saavatko potilaat niitä tasavertaisesti asuinpaikkakunnasta riippumatta.

"saavatko kaikki hyvää saattohoitoa riippumatta asuin- tai hoitopaikasta"

"miten saattohoito toteutetaan ja miten se pitäisi toteuttaa laajassa Lapin maassa"

Eri hoitoympäristöt hoidon toteuttajina vaativat ammattilaisten mukaan tarkempaa tutkimusta, esimerkiksi selvitystä saattohoidon saatavuudesta ja potilaiden kokemuksista erilaisissa hoitopaikoissa. Retrospektiivistä tutkimusta tarvitaan potilaiden kuolinpaikoista ja arvioita hoitopaikan oikeasta valinnasta. Myös palliatiivisen hoidon ja saattohoidon kustannusvaikuttavuutta tulee tutkia, esimerkiksi kotisaattohoidon toteutuksessa.

"kotona tapahtuvan saattohoidon/palliatiivisen hoidon taloudellista vaikuttavuutta, onko siitä oikeasti hyötyä ja kenelle”

"palliatiivisessa hoidossa/saattohoidossa olevien kokemukset kotihoidossa, kodinomaisissa olosuhteissa vs. sairaalassa, osastolla"

\section{POTILAASEEN LIITTYVÄT TUTKIMUSKOHTEET}

Eri kulttuuritaustoista tulevat potilaat ja heidän hoitonsa toteutuminen kulttuuria kunnioittaen on työryhmien mukaan tutkimuskohteena tärkeä. Erityisesti kuoleman läheisyys ja sen kulttuurisuus tutkimuskohteena on alue, josta tarvitaan tutkimusta.

"hoitotieteessä tarvitaan lisää kotimaista/pohjoismaista tutkimusta palliatiivisesta hoitotyöstä/saattohoidosta... monikulttuurisuus saattohoidossa"

Eri potilasryhmien kokemuksia palliatiivisesta hoidosta ja saattohoidosta tutkimusaiheena ammattilaiset nostivat esiin eri ikäisten potilaiden, kehi- tysvammaisten ja mielenterveyspotilaiden sekä vanhusten kokemukset.

"lasten ja nuorten kokemusten tutkiminen"

"erityisryhmien tarpeet (esim. kehitysvammaja mielenterveyspotilaat sekä tasa-arvoisen hoidon järjestäminen kaikkiin potilasryhmiin”

Potilaiden tuen tarpeet ja niiden tunnistaminen kohdistavat tutkimuksen potilaiden kokemuksiin saamastaan tuesta ja vielä yksilöidymmin saadusta eksistentiaalisesta tuesta erityisasiantuntijoita hyödyntäen. Saattohoitovaiheessa olevan potilaan tuen tarpeet ja niiden tunnistaminen ovat yksi ammattilaisten esiin nostamista aiheista.

"mentaalisen puolen tutkimus (kosketus, läsnäolo ja tarpeet)"

"tutkimuksen kohteena potilaat ja heidän kokemuksensa/näkemyksensä mm. psykososiaalinen tuki”

\section{HOITOON LIITYYÄT TUTKIMUSKOHTEET}

Eri sairauksien monitieteinen tutkimus sisältää palliatiivista hoitoa vaativien sairauksien kuten syöpätautien ja muistisairauksien tutkimusta sekä tautikohtaisten hoitojen keston tutkimusta ennen potilaan kuolemaa. Ammattilaiset ehdottivat, että hoitopäätöksiä tulisi arvioida diagnoosikohtaisesti sekä niiden yhteyksiä potilaan kuolemaan. Myös hoidon priorisointitutkimusta tarvitaan, samoin kuin geeniteknologista tutkimusta.

"Niiden sairauksien tunnistaminen, jotka johtavat aina palliatiivista hoitoa ja tämän tiedon tuottaminen myös kaikkien tietoisuuteen”

Hoidon laatu ja sen mittaaminen ovat ammattilaisten arvion mukaan tärkeä tutkimuskohde. Suomeen pitäisi luoda valtakunnalliset hyvän hoidon kriteerit ja yhtenevät laatumittarit. Hoidon laadun arviointien tulokset olisivat silloin vertailukelpoisia valtakunnallisesti. Myös valtakunnallisesti yhtenevien hoidon linjausten ja rajausten kriteerit pitää luoda. Auditointijärjestelmä tutkimuskohteena on tulevaisuudessa tärkeää, samoin $\mathrm{ABC}$ mallin (perustaso A, erityistaso $\mathrm{B}$, vaativa erityistaso C) toimivuuden arviointitutkimus. Tarvitaan validit menetelmät hoidon vaikuttavuuden ja kustannustehokkuuden arviointiin. 
"saattohoidon laatu ja vaikuttavuus ihmislähtöisesti ja kuinka kustannustehokasta saattohoito on"

"mittareiden avulla vakiointia, systemaattista tiedon keräämistä ja sen hyödyntämistä”

Lääkkeelliset hoitomenetelmät tutkimuskohteena sisälsi ammattilaisten mukaan palliatiivisen hoidon lääketutkimusta erityisesti kipu-, pahoinvointi- sekä mielialalääkkeiden edelleen kehittämisestä sekä lääkehoidon vaikuttavuuden arvioinnista.

"lääkehoidon vaikuttavuus"

"palliatiivisen hoidon lääketutkimukset"

Lääkkeettömät ja vaihtoehtoiset auttamismenetelmät tutkimuskohteena tarkoittaa ammattilaisten mukaan esimerkiksi potilaan omien sisäisten selviytymiskeinojen tunnistamista. Kiinalaisen lääketieteen käyttämien auttamismenetelmien, kuten akupunktion käyttöä potilaan kivunhoidossa, samoin kuin muitakin lääkkeettömiä kivunhoidon menetelmiä pitäisi tutkia.

"vaihtoehtoiset hoitomenetelmät ja kosketus"

Eettiset kysymykset tutkimusaiheena kohdentuvat potilaan hoitotahdon ja itsemääräämisoikeuden toteutumiseen hoidossa. Eri potilasryhmien tasa-arvon toteutuminen hoidossa on yksi eettinen kysymys, joka vaatii selvittämistä. Yksi ryhmä nosti myös eutanasian tulevaisuuden tutkimuskohteeksi.

"itsemääräämisoikeuden kunnioittaminen ja edellytykset itseään koskevaan päätöksentekoon"

Uudet teknologiat ja digitalisaatio ovat vastaajien mukaan yksi palliatiivisen ja saattohoidon tutkimusalue. Älylaitteiden hyödyntäminen ja terveysteknologian tuomat mahdollisuudet vaativat tutkimusta. Digitaalisuus on osa hoitoa ja tietojärjestelmistä saatavaa tietoa ja sen hyödyntämistä tulee tutkia esimerkiksi arvioitaessa teknologian käytön hyötyjä potilaan kokeman elämänlaadun turvaamisessa.

"digitaalisen hoidon mahdollisuudet: etähoito, oman tilan seuranta, tietojärjestelmien tarjoa- ma tiedon tarkempi hyödyntäminen sekä teknologian kehittämät tekniset apuvälineet terveydenhuollon käyttöön"

\section{LÄHEISIIN LIITTYYÄT TUTKIMUSKOHTEET}

Läheisten tukeminen kuuluu yhtenä tärkeänä osaalueena ammattilaisten nimeämiin tutkimuskohteisiin. Läheisten tuen tarpeiden tunnistaminen ja heidän kokemuksensa saamastaan psykososiaalisesta tuesta, ennen ja jälkeen potilaan kuoleman, nimettiin tärkeiksi tutkimuskohteiksi. Erikseen mainittiin omaisten kokemukset saamastaan tuesta surutyön aikana.

"läheisten selviytyminen potilaan kuoleman jälkeen, toivon tutkiminen”

"hyvin toteutuneessa palliatiivisessa hoidossa omaisten kannattelu, miten se tapahtuu, kun se onnistuu, millaista tukea omaiset toivovat, millaista tukea he saavat, miten tuki tulisi järjestää?”

Läheisten kokemuksia hoidon laadusta pitäisi selvittää aiempaa tarkemmin. Ammattilaiset nimesivät erityisesti saattohoidon laadun ja sen yhteyden läheisten kokemuksiin. Potilaan lääkehoidon toteutuminen läheisten arvioimana on tärkeää. Myös läheisten arviota hoitopalautteen antamisen oikea-aikaisuudesta pitäisi selvittää.

\section{AMMATTIHENKILÖSTÖÖN LIITTYVÄT TUTKIMUSKOHTEET}

Eri ammattiryhmien kokemukset kuolevan potilaan kohtaamisesta ja hoitamisesta tutkimuskohteena nostettiin esille. Moniammatillisessa työryhmässä työskentelystä tarvitaan myös tutkimustietoa.

Ammattihenkilöstön osaamisen ja osaamisen johtamisen tutkimuksessa tulisi selvittää hyvän palliatiivisen hoidon ja saattohoidon lääkärin ja hoitajan ominaisuudet. Koulutuksen vaikuttavuus ammattihenkilöstön osaamiseen ja osaamisen johtaminen nostettiin esiin tutkimusaiheina.

"saadaanko koulutuksen lisäämisellä tulokseksi parempaa saattohoitoa"

"johtamisen kysymykset: osaamisen kehittäminen, tunteet, työntekijöiden vaihtuvuus, osaamisen johtaminen, työntekijöiden valitseminen osastolla (millä kriteereillä, kenelle sopii)" 
Henkilöstön työhyvinvointia tutkimuskohteena tulisi ammattilaisten mukaan tarkastella henkilöstön työhyvinvointiin yhteydessä olevien tekijöiden tunnistamisen näkökulmista, kuten ammatillisen osaamisen yhteys työhyvinvointiin. Erityisesti hoitajien jaksaminen ja vaihtuvuus sekä niihin yhteydessä olevat tekijät tulisi tutkimustiedon perusteella huomioida.

"miten henkilöstön jatkuva vaihtuminen vaikuttaa potilaan tilaan"

\section{VAPAAEHTOISTYÖHÖN LIITTYVÄT TUTKIMUSKOHTEET}

Vapaaehtoistyöhön kohdistuvaa tutkimusta tarvitaan, erityisesti arviota vapaaehtoisten henkilöiden osallistumisesta palliatiiviseen hoitoon ja saattohoitoon sekä heidän kokemuksiaan hoidosta.

"vapaaehtoisten hyödyntäminen saattohoitotyössä. Miten tulee vaikuttamaan palliatiivisen ja saattohoidon kehittämisessä.”

\section{MONITIETEISEEN TUTKIMUKSEEN LIITTYÄT TUTKIMUSKOHTEET}

Työryhmät pitivät tärkeänä monitieteistä tutkimusta palliatiivisessa hoidossa ja saattohoidossa. Lähitulevaisuudessa olisi hyvä perustaa kansallisia ja kansainvälisiä tutkimusryhmiä. Työryhmät esittivät myös nimenomaan surututkijoiden kutsumista tutkimusryhmiin muiden tutkijoiden ohella. Surun lisäksi tässä teemassa ei kuvattu muita tarkempia monitieteisen tutkimuksen aiheita.

\section{POHDINTA}

\section{TULOSTEN TARKASTELU}

Tutkimuksen tulosten perusteella palliatiivisen hoidon ja saattohoidon tärkeimmät kehittämiskohteet lähitulevaisuudessa kohdistuivat palvelujärjestelmään,palveluidentasa-arvoiseen saatavuuteen, kotisaattohoitoon sekä hoidon toteutukseen.

Palliatiivisen hoidon ja saattohoidon kehittämis- ja tutkimuskohteissa painottui hoitokäytäntöjen rakenteellinen ja sisällöllinen kehittäminen varsinaisten oirehoitomenetelmien ja lääketutkimuksen jäädessä vähemmälle huomiolle. Tämä saattaa liittyä työryhmien kokoonpanoihin, joissa painottui hoitajien osuus (75\%), kun taas lääkäreitä (12\%) ja muita alan asiantuntijoita (13\%) oli huomattavasti vähemmän.
Tämän tutkimuksen tulosten perusteella palliatiivisen hoidon toimintaympäristöä tulisi kehittää valtakunnallisesti, alueellisesti ja paikallisesti hoidon tasa-arvoisen saatavuuden varmistamiseksi. Aikaisemmat tutkimukset tukevat tätä tulosta $(13,14,7)$. Ihmisoikeutena sen tulisi kuitenkin olla kaikkien saatavilla (7). Työryhmien mukaan potilaiden yhdenvertaisuutta palvelun saatavuudessa etenkin haja-asutusalueilla voitaisiin parantaa kehittämällä etähoitoa, potilastietojärjestelmiä sekä rajaseutuyhteistyötä. Nämä mainitut kehittämismenetelmät lisäisivät mahdollisuutta perustuslailliseen oikeuteen palveluiden tasavertaisesta saatavuudesta asuinpaikasta riippumatta. Vaikka Suomessa ei ole varsinaista palliatiivisen hoidon ja saattohoidon lakia, muu lainsäädäntö painottaa potilaan autonomiaa ja itsemääräämisoikeutta. (3.) Myös Hasson ym. (25) tunnistivat katsauksessaan yhdeksi palliatiivisen hoidon tärkeäksi tutkimuskohteeksi epätasa-arvon kysymykset.

Hasson ym. (25) totesivat, että palliatiivisen hoidon palvelumallit ja hoidon jatkuvuus ovat tärkeitä tutkimuskohteita. Myös tässä tutkimuksessa nämä kysymykset tulivat esille. Työryhmien ehdotuksen mukaisesti palliatiivisen hoidon ja saattohoidon saavutettavuutta voisi parantaa kotisaattohoidolla. Kotisaattohoito edellyttää hyvää kotisairaalatoimintaa ja sen kehittämistä. Aikaisemman tutkimustiedon mukaan perusterveydenhuollon vahvistaminen palliatiivisen hoidon ja saattohoidon osaajana tuo hyötyä potilaille, heidän läheisilleen sekä erikoissairaanhoidolle, ja lopulta koko yhteiskunnalle. $(3,20,19$.) Perusterveydenhuollon vahvistaminen edellyttää myös ammattilaisten osaamisen kehittämistä sekä tukirakenteiden, kuten konsultaatiotoiminnan, luomista myös päivystysaikaan (14).

Työryhmissä ehdotettiin lisäksi erityistason kotisaattohoidon kehittämistä. Palliatiiviset erityistason kotisairaalat ovat palveluketjun keskiössä, ja ne tukevat perustason yksiköitä ja sosiaalitoimen vanhus- ja vammaispalveluita sekä toimivat siltana perus- ja erityistason yksiköiden välillä (14). Saarto ja työryhmä (2019b) toteavat, että kuitenkin niiden kattavuus on tällä hetkellä puutteellista (14).

Tämän tutkimuksen tulokset vahvistavat aikaisempia tutkimustuloksia ja suosituksia siitä, että palliatiivinen hoito ja saattohoito tulisi in- 
tegroida osaksi sosiaali- ja terveyspalvelujärjestelmää $(1,5,6)$. Suomessa on tehty viimeisten vuosien aikana runsaasti valtakunnallista kehittämistyötä. Esimerkiksi sosiaali- ja terveysministeriö (STM) on nimittänyt asiantuntijatyöryhmän, joka on antanut suositukset palliatiivisen hoidon laatukriteereistä, hoidon palveluiden tuottamisesta ja laadun parantamisesta $(13,14)$.

Yhtenäisillä hoitolinjauskäytännöillä on keskeinen merkitys palliatiivisen hoidon laadun varmistamisessa. Hoidon toteutuksen monitieteisessä kehittämisessä tarvitaan alan ammattilaisten mukaan yhtenäiset hoitolinjaukset ja -käytänteet, joiden noudattamiseen kaikki sitoutuisivat potilaan hoidossa. Nämä edellyttävät tutkimusnäyttöön perustuvien, ymmärrettävien ja helposti saatavilla olevien ohjeiden saatavuutta. Suomessa on jo julkaistu palliatiivisen hoidon ja saattohoidon Käypä hoito -suositukset (Lääkäriseura Duodecim) (4), mutta hoitotyön suosituksia (Hoitotyön Tutkimussäätiö) vasta laaditaan. Parhaillaan Hoitotyön Tutkimussäätiön työryhmä valmistelee hoitotyön suositusta palliatiivisessa hoidossa ja saattohoidossa olevan potilaan tukemiseen. Aihe nousi myös tässä tutkimuksessa yhdeksi tärkeäksi kehittämiskohteeksi. Hoitotyön suosituksia on valmisteilla myös saattohoitopotilaan lääkkeettömistä kivunhoitomenetelmistä (15). Aikaisemman tutkimustiedon perusteella etenkin potilaat ovat toivoneet, että ammattilaisilla olisi enemmän tietoa näistä auttamismenetelmistä ja niiden käytöstä (23). Vaikka lääkkeettömiä auttamismenetelmiä on käytetty pitkään esimerkiksi syöpäpotilaiden hoidossa, tutkimusnäyttöä aiheesta ei ole vielä kovin paljon saatavilla (30).

Palliatiivisessa hoidossa ja saattohoidossa lääkehoidon toteutus on keskeisessä roolissa. Aiheen kehittämiskohteita ovat lääkkeiden saatavuus ja toteutuksen joustavuus. Lääkehoidon kehittäminen ja vaikuttavuuden tutkiminen nousivat tämän tutkimuksen tulosten perusteella esille vain muutamissa työryhmissä. Lääkehoidosta päättäminen on tärkeä osa lääkärin työtä. Tämän tutkimuksen työryhmissä suurin osa osallistujista oli hoitajia. On mahdollista, että siksi lääkehoidon tärkeys näyttäytyi tässä aineistossa enemmän praktisina ehdotuksina, kuten lääkkeiden saatavuuteen keskittyvänä kehittämisenä. STM:n selvityksessä (2017) todetaan, että sosiaalihuollon lääkehuollon järjestämistä ja rahoitusta koskevat säädökset tarvitsevat ajantasaistamista, jotta asianmukainen palliatiivisen hoidon ja saattohoidon lääkitys olisi sujuvasti toteutettavissa. Yhtenä esimerkkinä lainsäädäntötyön etenemisestä on parhaillaan valmistelussa oleva sosiaalihuollon asumispalveluyksiköiden akuuttilääkevarastot (31).

Työryhmien mukaan palliatiivisen hoidon ja saattohoidon tarpeesta ja merkityksestä tarvitaan asiantuntijatason keskustelun lisäksi yhteiskunnallista keskustelua. Yhtenä esimerkkinä esitettiin yleistä keskustelua hoitotahdosta ja sen tekemisestä. Alan ammattilaisten mukaan hoitotahdon tekeminen hyödyttäisi niin koko palliatiivisen hoidon verkostoa kuin potilasta ja hänen läheisiään. Tulosten mukaan kaikille kansalaisille, mukaan lukien osa sosiaali- ja terveydenhuollon henkilöstöstä, palliatiivisen hoidon ja saattohoidon käsitteet ovat epäselvät. Usein saatetaan ajatella, että palliatiivista hoitoa tarvitsevat ovat vain syöpäpotilaita. Hoitoa tarvitsevat kuitenkin myös muita pitkälle edenneitä sairauksia sairastavat potilaat, joiden elämänlaatua voidaan kohentaa monin tavoin. Tämän tutkimuksen tulosten mukaan alan ammattilaiset nimesivät tärkeiksi tutkimuskohteiksi esimerkiksi eri ikäiset potilaat kuten lapset, mieluummin kuin diagnoosilähtöisen lähestymistavan.

Tärkeiksi tutkimusalueiksi on aikaisemmin tunnistettu myös palliatiivisen hoidon koulutus, kommunikaatio, hyvä ja itsenäinen elämä, sekä perheen tai hoitavan henkilön tarpeet ja perheiden tärkeys (25). Nämä ilmenivät tämän tutkimuksen tuloksissa siten, että koulutusohjelmien kehittäminen ja perhekeskeisyyden kehittäminen olivat tunnistettuja kehittämiskohteita. Perheen tai hoitavan henkilön tarpeita ja perheiden tärkeyttä kuvastavat tässä tutkimuksessa tunnistetut läheisten tukeminen ja läheisten kokemukset hoidon laadusta tutkimuskohteena sekä perhekeskeisyys kehittämiskohteena. Potilaan hyvän ja itsenäisen elämän voidaan ajatella liittyvän ainakin osittain tässä tutkimuksessa tunnistettuihin potilaaseen liittyviin tutkimuskohteisiin. Kommunikaatiota tässä tutkimuksessa ei suoranaisesti otettu esille tutkimus- tai kehittämiskohteena. Kuitenkin kommunikaatio on saattanut liittyä tutkittavien ajatuksiin jonkin muun laajemman aiheen sisällä, esimerkiksi potilaiden ja perheiden tukemiseen liittyvissä aiheissa, vaikka sitä ei ollutkaan erityisesti mainittu. 
Hasson ym. (25) havaitsivat katsauksessaan, että harvoissa alkuperäistutkimuksissa potilaat olivat olleet tiedonantajina. Jotta palliatiivisen hoidon ja saattohoidon kehittämis- ja tutkimuskohteista saadaan aidosti asiakas- ja potilaslähtöistä tietoa, tulee jatkossa potilaita osallistaa myös kehittämis- ja tutkimusaiheiden muotoiluun.

Kliinisessä työssä ja muissa potilaan ja perheiden auttamistehtävissä toimivilta palliatiivisen hoidon ja saattohoidon ammattilaisilta on kerätty suhteellisen harvoin tietoa siitä, mitkä heidän näkemyksensä mukaan ovat tärkeitä alan kehittämis- ja tutkimuskohteita, ja tämä tutkimus tuotti aiheesta sekä aiempaa tutkimustietoa vahvistavaa että uutta, ennen raportoimatonta tietoa.

\section{TUTKIMUKSEN LUOTETTAVUUS}

Tutkimuksen luotettavuutta sen valmisteluvaiheessa (32) paransi se, että menetelmä sopi tutkimuksen tarkoitukseen. Koska aineisto oli laaja ja edusti useita ammattialoja, voidaan arvioida, että se edusti kiinnostuksen kohteena olevaa ilmiötä melko hyvin. Koska esimiehet ehdottivat henkilökunnastaan sopivimpia edustajia työpajaan, ei ole tiedossa, oliko kieltäytymisiä. Kukaan niistä, joiden yhteystiedot saatiin, ei kieltäytynyt siinä vaiheessa, kun tutkijat olivat heihin yhteydessä. Työpajassa käytetyn kyselylomakkeen sisältö rakennettiin kirjallisuuteen perustuen. Tämä lisäsi itse tehdyn lomakkeen luotettavuutta. Valittu analyysiyksikkö oli joustava, eikä ollut vaaraa, että se olisi liian kapea tai liian laaja, joten se oli sopiva tämän tutkimuksen tarkoitukseen.

Luotettavuutta heikentävät itse laadittu validoimaton kyselylomake sekä se, että koska työpajat järjestettiin vain kerran, tutkijoilla ei ollut mahdollisuuksia esittää tutkittaville lisäkysymyksiä, jotta olisi voitu syventää ymmärrystä tutkimuksen kohteena olevasta ilmiöstä. Esimerkiksi analyysiä vaikeutti toisinaan se, että työryhmät olivat vastanneet vain yhdellä käsitteellä esimerkiksi "terveysteknologia", kun heitä pyydettiin kuvailemaan kehittämiskohteita. Näin ollen terveysteknologiasta ei voitu tehdä pidemmälle meneviä johtopäätöksiä.

Käsikirjoituksia ei lähetetty tutkittaville kommentoitavaksi tai korjattavaksi, eikä tutkimuksen tuloksia esitetty heille, jotta he voisivat antaa niistä palautetta. Se ei olisi ollut mahdollista- kaan, koska tutkimukseen osallistujille oli luvattu, että heidän yksityisyyttään suojellaan ja henkilörekisteriä ei muodostettu. Vaikka tutkittavien joukossa oli useiden eri alojen ammattilaisia, yksi rajoitus on se, että hoitajien ryhmä oli paljon suurempi kuin muiden ammattilaisten ja siten tulokset voivat heijastella enemmän heidän näkemyksiään kuin muiden.

Tutkimuksen organisointivaiheessa (32) luotettavuutta paransi se, että yksi kokenut tutkija analysoi koko aineiston. Muu tutkimusryhmä perehtyi aineistoon ja tarkasteli kriittisesti pääanalysoijan tekemää analyysiä. Kaikki arvioivat analyysissä tuotettua käsitejärjestelmää, jotta varmistuttiin siitä, että teemoittelu oli looginen ja teemat olivat toisensa poissulkevia. Vain ilmisisältöjä analysoitiin, mikä varmistaa sen, että tulokset edustavat tutkittavien antamaa informaatiota.

Tutkimuksen raportointivaiheessa (32) luotettavuutta paransi se, että raportoinnissa on pyritty käytettyjen menetelmien ja tulosten tarkkaan raportointiin. Lainauksia alkuperäisaineistosta on käytetty, jotta lukijoilla olisi mahdollisuus tavoittaa esimerkkejä alkuperäisaineistosta. Tutkimuksen kontekstin, analyysin ja tulosten kuvausten perusteella lukijat voivat arvioida tulosten siirrettävyyttä muihin konteksteihin.

\section{JOHTOPÄÄTÖKSET}

Tutkimuksessa tuotettiin uutta tietoa palliatiivisen hoidon ja saattohoidon lähitulevaisuuden kehittämistarpeista asiantuntijoiden näkökulmasta. Työryhmien esittämät näkemykset palliatiivisen hoidon ja saattohoidon kehittämisestä ovat linjassa STM:n nimittämän asiantuntijatyöryhmän antamien suositusten kanssa. $(13,14$.)

Alojen tärkeimpinä kehittämiskohteina ovat palvelujärjestelmän rakenteiden ja prosessien kehittäminen palvelun tasa-arvoisen saatavuuden varmistamiseksi. Hoidon toteutukseen kaivataan erilaisia toteutustapoja, jotka parantavat hoidon saavutettavuutta erityisesti haja-asutusalueilla. Näitä ovat esimerkiksi kotisairaalatoiminta ja kotona toteutettava saattohoito.

Hoidon laadun varmistamiseksi olisi tärkeää saada monitieteellinen hoitosuositus ja laatia alan osaamisen kehittämisen suunnitelma ja aloittaa sitä toteuttavaa koulutusta kansallisena yhteistyönä. Hoidon laadun varmistamiseksi tarvitaan vielä runsaasti monitieteellistä tutkimusta 
ja hoidon vaikuttavuuden seurantaa. Tutkimuksessa tulisi hyödyntää yhä enemmän kansallisia, koko väestön tiedot kattavia rekistereitä.

Tässä tutkimuksessa tuotiin esiin erilaisia osa-alueita, joissa tutkimukseen osallistuneiden asiantuntijoiden mukaan on kehittämis- ja tutkimustarpeita. Laadukkaan palliatiivisen hoidon ja saattohoidon turvaamiseksi tarvitaan myös systemaattista kehittämistä palliatiivisen hoidon koulutuksessa, organisoinnissa ja käytänteissä.

\section{RAHOITTAJAT:}

Tutkimus toteutettiin "Palliatiivisen hoitotyön ja lääketieteen koulutuksen monialainen ja työelämälähtöinen kehittäminen- EduPal” hankkeessa, joka on Opetus ja kulttuuriministeriön rahoittama korkeakoulutuksen kehittämisen kärkihanke. Korkeakoulutuksen kehittämishankkeet ovat korkeakoulujen yhteishankkeita, joilla tavoitellaan valtakunnallista vaikutusta.

\section{KIRJOITTAJIEN KONTRIBUUTIOT}

Kaikki kirjoittajat osallistuivat tutkimuksen alkuun saattamiseen ja suunnitteluun sekä aineiston keräämiseen. Lehto ja Hökkä laativat kyselylomakkeen. Salin analysoi aineiston ja Melender, Lehto ja Hökkä tarkastelivat analyysia kriittisesti sekä osallistuivat analyysin viimeistelyyn. Kaikki osallistuivat artikkelin luonnostelemiseen ja tarkistivat sen kriittisesti, hyväksyivät artikkelin lopullisen version sekä ottavat vastuun sen kaikista osa-alueista.

Salin, S, Melender, H-L, Lehto, J.T, Hökkä, M. Experts' perspectives on the research and development needs of palliative care and end-of-life care. Sosiaalilääketieteellinen aikakauslehti - Journal of Social Medicine $202 \mathrm{I}$ : 58: | 43-I 57.

Palliative care is the active and comprehensive care of patients with incurable, fatal or life-threatening illnesses that also considers their loved ones. According to the $\mathrm{WHO}$, the greatest per capita growth in the need for palliative care will in the near future be in Europe. There have been few studies on expert perspectives on the development of palliative care in Finland. The purpose of this study was to collect the views of palliative care experts $(n=222)$, working in groups $(n=36)$, on the most important near-future research and development needs in the field. The data were collected in Spring 2018 and consisted of the answers produced by the groups to two open questions, which were then analyzed through thematic analysis. The results show that the most important areas of development are related to work environments, care practices and staff skills, while the most important areas of research are related to work environments, patients and their loved ones, care, professional staff, voluntary work and multidisciplinary research. The study produced significant information about the most important areas of research in end-of-life care to ensure an equal quality of care regardless of the patient's residence. The groups recommended research into all areas of care.

Keywords: palliative care, end-of-life care, development, research.

$$
\begin{array}{cc}
\text { Saapunut } & (12.05 .2020) \\
\text { Hyväksytty } & (08.01 .2021)
\end{array}
$$

\section{LÄHTEET}

(1) Connor S, Bermedo M. Global atlas of Palliative Care. WHO Global Atlas of Palliative Care at the End of Life. Worldwide Palliative Care Alliance and World Health Organization. 2014. Luettu 21.2.2020. https://www.who.int/nmh/ Global_Atlas_of_Palliative_Care.pdf

(2) World Health Organization. WHO definition of palliative care. 2020. Luettu 21.2.2020. http:// www.who.int/cancer/palliative/definition/en/.

(3) STM 2017. Palliatiivisen hoidon ja saattohoidon järjestäminen. Työryhmän suositus osaamis- ja laatukriteereistä sosiaali- ja

terveydenhuollon palvelujärjestelmälle. Sosiaalija terveysministeriön raportteja ja muistioita 2017:44. Luettu 21.2.2020. http://urn.fi/ URN:ISBN:978-952-00-3896-0.

(4) Palliatiivinen hoito ja saattohoito. Käypähoitosuositus. Suomalaisen Lääkäriseuran Duodecimin ja Suomen Palliatiivisen Lääketieteen yhdistyksen asettama työryhmä. Helsinki: Suomalainen Lääkäriseura Duodecim 2019. Luettu 21.2.2020. www.kaypahoito.fi.

(5) Callaway M, Connor S, Foley K. World Health Organization Public Health Model: A Roadmap 
for Palliative Care Development. Journal of Pain and Symptom Management 2018; 55(2S): S6-S12.

https://doi.org/10.1016/j.

jpainsymman.2017.03.030

(6) Meier D, Beresford L. Health Systems Find Opportunities and Challenges in Palliative Care Development. Journal of Palliative Medicine 2010; 13(4): 367-370.

https://doi.org/10.1089/jpm.2010.9848

(7) Council of Europe: Committee on Social Affairs, Health and Sustainable Development. 2018. The provision of palliative care in Europe. Document 14657. Luettu 21.2.2020. http://semanticpace. net/tools/ pdf.aspx?doc=aHR0cDovL2

Fzc2VtYmx5LmNvZS5pbn

QvbncveG1sL1hSZWYvWDJ

ILURXLWV4dHIuYXNwP2ZpbG

VpZD0yNTA1NyZsYW

5nPUVO\&xsl=aHR0cDov

L3NlbWFudGljcGFjZS5uZXQvW

HNsdC9QZGYvWFJIZi1XRC1BV

C1YTUwyUERGLnhzbA== \&xsltparams=

ZmlsZWlkPTI1MDU3

(8) Lynch T, Connor S, Clark D. Mapping Levels of Palliative Care Development: A Global Update. Journal of Pain and Symptom Management 2013; 45(6): 1094-1106.

https://doi.org/10.1016/j.

jpainsymman.2012.05.011

(9) Suomen Palliatiivisen Hoidon Yhdistys ry. Luettu 4.5.2020. https://www.sphy.fi/

(10) Suomen Palliatiivisen Lääketieteen Yhdistys. SPLY. Luettu 4.5.2020 https://www. palliatiivisenlaaketieteenyhdistys.fi/

(11) Woitha K, Martin-Moreno J, Clark D, ym. Ranking of Palliative Care Development in the Countries of the European Union. Journal of Pain and Symptom Management 2016; 52(3): 370-376.

https://doi.org/10.1016/j. jpainsymman.2016.03.008

(12) Froggatt K, Payne, S, Morbey H, ym. On behalf of PACE (2017). Palliative care development in European care homes and nursing homes: Application of a typology of implementation. The Journal of Post-Acute and Long-Term Care Medicine 18 (6); 550e7-550e14. https://doi.org/10.1016/j.jamda.2017.02.016

(13) Saarto T, Finne-Soveri H. ja asiantuntijatyöryhmät. Palliatiivisen hoidon ja saattohoidon tila Suomessa. Alueellinen kartoitus ja suositusehdotukset laadun ja saatavuuden parantamiseksi. 2019a. Luettu 11.3.2020.

http://urn.fi/URN:ISBN:978-952-00-4041-3

(14) Saarto T, Finne-Soveri H. Suositus palliatiivisen hoidon palveluiden tuottamisesta ja laadun parantamisesta Suomessa: Palliatiivisen hoidon asiantuntijaryhmän loppuraportti. Sosiaali- ja terveysministeriön raportteja ja muistioita 2019:68. 2019b. Luettu 14.3.2020. http://urn.fi/URN:ISBN:978-952-00-4126-7
(15) Valmisteilla olevat hoitotyön suositukset. Luettu 7.5.2020. https://www.hotus.fi/valmisteillaolevat-hoitosuositukset

(16) Palliatiivisen hoitotyön ja lääketieteen koulutuksen monialainen ja työelämälähtöinen kehittäminen - EduPal. Luettu 15.4.2020. https:// www.palliatiivisenkoulutuksenkehittaminen.fi/

(17) May P, Normand C, Cassel JB, ym. Economics of Palliative Care for Hospitalized Adults with Serious Illness. A Meta-analysis. JAMA Internal Medicin 2018; 178: 820-829. https://doi.org/10.1001/ jamainternmed.2018.0750

(18) Maetens A, Beernaert K, Schreye RD, ym. Impact of palliative home care support on the quality and costs of care at the end of life: a population-level matched cohort study. BMJ 2019; Open. 9; e025180. https://doi.org/10.1136/bmjopen-2018-025180

(19) Hänninen J. Saattohoito kotona vaatii monenlaista tukea.2013. Luettu 14.4.2020. https://www.laakarilehti.fi/ajassa/paakirjoitukset/ saattohoito-kotona-vaatii-monenlaista-tukea/

(20) Schelin M, Sallerfors B, Rasmussen B, ym. Quality of care for the dying across different levels of palliative care development: A population-based cohort study. Palliative Medicine 2018; 32(10): 1596-1604. https://doi.org/10.1177/0269216318801251

(21) Smets T, Van dop N, Pivodic L, ym. Palliative care knowledge of nursing home staff in six European Countries: PACE cross-sectional study. Palliative Medicine Jul 2018. Published Online (Avoin tieteellinen julkaisu). Luettu 13.4.2020. http://journals.sagepub.com/ doi/pdf/10.1177/0269216318785295

(22) Piili R. End-of-life decision-making in cancer patients: attitudes, ethics and background factors among Finnish physicians and medical students. Väitöskirja: Tampereen yliopisto, lääketieteen ja terveysteknologian tiedekunta, 2019.

(23) Pelto A-K, Hökka M, Kajula O, ym. Kivunhoidon ohjaus syöpää sairastavan potilaan ja hänen läheistensä kuvaamana palliatiivisessa hoidossa - integroitu kirjallisuuskatsaus. Tutkiva Hoitotyö 2019; 17(2): 22-29.

(24) Selman L, Young T, Vermandere M, ym. Research priorities in spiritual care: an international survey of palliative care researchers and clinicians. Journal of Pain and Symptom Management 2014; 48(4): 518-531. https://doi.org/10.1016/j. jpainsymman.2013.10.020

(25) Hasson F, Nicholson E, Muldrew D, ym. 2020. International palliative care research priorities: A systematic review. BMC Palliative Care 19(1);16. doi: 10.1186/s12904-020-0520-8. https://doi.org/10.1186/s12904-020-0520-8

(26) Vaismoradi M, Turunen H, Bondas T. Content analysis and thematic analysis: Implications for conducting a qualitative descriptive study. Nursing and Health Sciences 2013; 15: 398-405. https://doi.org/10.1111/nhs.12048 
(27) Saaranen-Kauppinen A. \& Puusniekka A. 2006. KvaliMOTV - Menetelmäopetuksen tietovaranto [verkkojulkaisu]. Tampere: Yhteiskuntatieteellinen tietoarkisto [ylläpitäjä ja tuottaja]. <https://www.fsd.tuni.fi/ menetelmaopetus/>. (Luettu 30.10.2020.)

(28) TENK. 2013. Hyvä tieteellinen käytäntö ja sen loukkausepäilyjen käsitteleminen Suomessa. Tutkimuseettisen neuvottelukunnan ohje 2012. Helsinki: Tutkimuseettinen neuvottelukunta. Luettu 13.2.2020. https://www.tenk.fi/sites/tenk. fi/files/HTK_ohje_2012.pdf

(29) TENK. 2019. Ihmiseen kohdistuvan tutkimuksen eettiset periaatteet ja ihmistieteiden eettinen ennakkoarviointi Suomessa. Helsinki: Tutkimuseettisen neuvottelukunnan julkaisuja 3/2019.

(30) Hökkä M, Kaakinen P, Pölkki T. A systematic review: nonpharmacological interventions in treating pain in patients with advanced cancer. Journal of Advanced Nursing 2014; 70(9): 1954 1969. https://doi.org/10.1111/jan.12424

(31) STM. 2020. STM ohjeistaa sosiaalihuollon asumispalveluyksiköitä lääkehuollon järjestämisessä. Tiedote 84/2020. Sosiaali- ja terveysministeriö. Luettu 29.4.2020. https:// stm.fi/artikkeli/-/asset_publisher/stm-ohjeistaasosiaalihuollon-asumispalveluyksikoitalaakehuollon-jarjestamisessa
(32) Elo S, Kääriäinen M, Kanste $O$, ym. Qualitative content analysis: a focus on trustworthiness. SAGE Open 2014; 4:1-10. http://sgo.sagepub. com/content/4/1/2158244014522633

https://doi.org/10.1177/2158244014522633

\section{Sirpa SALIN}

$T t T$, yliopettaja, gerontologinen hoitotyö

Tampereen ammattikorkeakoulu

Terveyspalvelut

Hanna-Leena Melender

TtT, Dosentti, yliopettaja, hoitotyö

Vaasan ammattikorkeakoulu

Sosiaali-ja terveysala

\section{JuHo T. LeHTO}

Professori, LT, Ylilääkäri

Tampereen yliopisto ja Palliatiivinen keskus

Lääketieteen ja terveysteknologian tiedekunta

Syöpätautien vastuualue, Tays.

\section{MinNa Нӧккё}

Sh YAMK, TtM, TtT-opiskelija, Hoitotyön lehtori

Kajaanin ammattikorkeakoulu

Sosiaali- ja terveysala 